\title{
Examine the Effect of State Ownership on the Relationship Between Internationalization and Technical Efficiency During 2015 ASEAN Economic Community: Evidence from Singapore-Listed Firms
}

\author{
Esti Kusuma Astadiyani ${ }^{1},{ }^{*}$ Wei-Hwa Pan ${ }^{2}$ \\ ${ }^{1}$ National Yunlin University of Science and Technology \\ ${ }^{2}$ Associate Professor, Department of Business Administration, National Yunlin University of Science and \\ Technology \\ *Corresponding author. E-mail: panwh@yuntech.edu.tw
}

\begin{abstract}
Since the industry transformation in 1965, Singapore established state-owned enterprises known as governmentlinked corporations to overcome the lack of private sector expertise and spearhead the development of its economy. Furthermore, Singapore proposed the "quasi-entrepreneur" strategy, encouraging firms to expand abroad. As a result, this research investigates the role of the government in the link between the degree of internationalization and technological efficiency in Singapore-listed enterprises. The study also examines the impact of the 2015 ASEAN Economic Community (AEC) on the relationship between those variables by dividing the periods into pre-economic integration and post-economic integration periods. Three hypotheses are developed and tested using Generalized least square (GLS) in Stata v.15, implemented on a sample of 117 firms across 31 industries from 2011-2020. The result shows an inverted U-shaped relationship between internationalization and technical efficiency, and firms with a low degree of state ownership outperform those with a high degree of state ownership. Furthermore, the finding suggests that economic integration affects the relationship between internationalization, technical efficiency, and degree of state ownership.
\end{abstract}

Keywords: Internationalization, Technical Efficiency, Economy Integration, State Ownership.

\section{INTRODUCTION}

Singapore has achieved significant economic development in the past few decades, owing a lot to its industry transformation. In 1965, the Singapore government transformed its industry by establishing state-owned enterprises known as governmentlinked corporations [1]. Furthermore, Singapore proposed the "quasi-entrepreneur" strategy, encouraging private and state-owned enterprises to expand their business abroad [2]. As a result, incremental privatization has offered Singapore's state-owned firms greater freedom to cope with technical difficulties and global competitiveness [3].

Unlike East Asian countries such as Taiwan, Japan, and South Korea, Singapore's economic growth was driven by government-linked corporations (GLCs) [1]. Though GLCs have contributed significantly to Singapore's economy, a recent debate regarding their economic viability. According to previous studies, state ownership has a detrimental influence on company performance because state-owned enterprises have been politically rather than commercially motivated [4], [5], [6].

However, in the case of Singapore, the impact of the state may not always be harmful [7], [8], [9]. As a result, this study investigates the impact of state ownership on the link between internationalization and performance as evaluated by technical efficiency and whether state ownership has a positive or negative impact on the technical efficiency of Singapore-listed enterprises. In particular, we firstly investigate the association between internationalization and technical efficiency in Singapore-listed firms. Secondly, we examine government ownership as the moderating effect on that association. Another focus of this study 
is to look into the impact of the 2015 ASEAN Economic Community (AEC) on the technical efficiency of Singapore-listed firms.

The AEC supports ASEAN enterprises by allowing the free movement of commodities, services, investment, money, and skilled labor within ASEAN, strengthening the region as a trade and production network [10]. According to the ERIA review in 2012, Singapore generally benefits from the AEC development. They ranked first in terms of trade facilitation, with the shortest day in ASEAN regarding the number of days required to complete cross-border trade. As a result, the development of EAC is considered to increase products and entrepreneurs from Singapore to dominate the ASEAN market [11]. The study's second contribution is to look at the impact of the ASEAN Economic Community on the link between internationalization and technical efficiency in Singapore-listed enterprises.

\section{LITERATURE REVIEW}

\subsection{Technical Efficiency}

Technical efficiency is a process's ability to create a specific quantity of products or services while using the fewest inputs [12]. Technical efficiency is related to the measurement of productivity. Productivity helps a company determine its efficiency by examining a certain quantity of inputs to produce the output [13]. When a company uses a small number of inputs to produce many products, it is technically efficient. The greater the number of results obtained for a given resource, the greater the technical efficiency [12].

\subsection{Measurement of Productivity and Efficiency}

Productivity and efficiency may be quantified using the "partial" or "total" factor basis. Because just one product is created from one input, measuring Partial Factor Productivity is comparatively straightforward. Partial Factor Productivity metrics, as a result, might offer deceptive estimates of overall productivity and efficiency since they present a partial view of the productivity with which the business utilizes its inputs [14]. To overcome the problem, Total Factor Productivity (TFP) to analyze business productivity and efficiency has become prevalent in the study literature. TFP is a more significant measure of productivity that encompasses all resources utilized to generate the products and services. [15].

\subsection{Internationalization}

The resource-based view (Wernerfelt, B., 1980) argues that companies engaging in international business activities need to exploit unique, valuable, and rare resources to achieve competitive advantage. This theory implies that internationalization is considered to increase the technical efficiency of companies by allowing them access to new resources [16], cutting manufacturing costs via economies of scale, and lowering R\&D, marketing, and distribution costs through economies of scope [17]. Internationalization not just reaps benefits but also comes with a set of costs. Internationalization may result in increased complexity and expense of coordination, particularly for primary overseas operations, and significant cultural differences between the home and foreign markets [16], [18].

Internationalization and performance are shown to have an inverted U-shape connection, according to the researchers [19], [20]. The advantages and disadvantages of internationalization are weighed together, establishing a curved relationship. At the early stage, degree of internationalization will increase firm performance by accessing cheaper or better resources and exploiting their products in foreign locations. At some point of internationalization or a high degree of internationalization, the relationship between benefits and costs reverses. Some researchers who believe in a U-shaped link between internationalization and performance have provided another rationale [21], [22], [23].

Additionally, the study revealed that internationalization and performance had an Sshaped relationship [24]. In the early phases of internationalization, costs are usually incurred well before profits. At medium degrees of internationalization, firms acquire and develop their particular assets and abilities, which benefits performance. However, given the complexities of managing overseas operations, excessive expansion may jeopardize athletic success once again.

Singapore is a highly competitive country with a small domestic market in the Singapore context. Internationalization is a way for Singapore firms to grow their markets and overcome the saturation in the domestic market [25]. As a result, this study postulates that the early stage of internationalization will boost the technical efficiency of Singaporelisted firms. However, a high degree of internationalization will decrease firm technical efficiency due to an overload of coordination, distribution, and management costs. H1. The DOI 
and the technical efficiency of Singapore-listed enterprises have an inverted U-shaped connection.

\subsection{State Ownership as a Contingency}

Although Singapore is not a socialist country, when it gained independence in 1965, the government adopted a "state capitalism" approach to economic development. State ownership, also known as state equity and public ownership, refers to a situation in which the government owns or controls property, a company, or an industry. As a result, the government established state enterprises known as government-linked companies or GLCs [1].

Privatization has been implemented progressively to boost Singapore's business flexibility. After establishing corporatized GLCs as important engines of domestic economic growth, the government took another step forward in 1974 by consolidating their operations under a single holding corporation, [26]. As state ownership expanded in the 1960s, it reversed in the 1980s, with Singapore governments gradually reducing their involvement and promoting private ownership [27]. Another goal was to increase private money for infrastructure development, decrease the state's budgetary load, enhance product quality, and lower consumer costs [3].

The section's original emphasis was on researching the influence of state ownership on the performance of Singapore-listed firms, even though empirical data produced inconsistent findings. According to some past studies, state ownership and performance are adversely correlated at a high level of state ownership, meaning that state ownership and performance are negatively correlated at a high level of state ownership [4], [5], [6]. On the other side, other experts claim that government ownership has a beneficial effect on performance. [8], [7], [9].

Secondly, the relationship between internationalization and state ownership in Singapore is notable. SOEs are established to remedy domestic market flaws and promote growth by manufacturing [28]. Hence, SOEs are relatively inward-looking and domestic orientated. As a result, SOEs are frequently unprepared to embark on an internationalization requiring specific managerial skills [29].

Singapore SOEs are in dominating position of overseas investments under their privileged to political access. In Singapore's case, its foreign investments have multiplied since the government proposed the "quasi- entrepreneur" strategy. Even though the "quasi-entrepreneur" strategy's primary goal is profit-oriented, overseas investments are sometimes subjected to political factors, resulting in inefficient investments.

H2. State ownership has a moderating effect on the link between DOI and technical efficiency of Singapore-listed enterprises.

\subsection{Economic Integration as a Contingency: ASEAN Economic Community 2015}

The ASEAN Economic Community, or AEC, is regarded as the economic impetus for ASEAN countries to come together and function as an economic bloc. In doing so, ASEAN Economic Community is founded on four pillars: a single market and manufacturing base, a competitive economic region, equitable economic development, and integration into the global economy [30].

The EAC 2015 is a watershed moment for ASEAN countries, particularly Singapore, as a great supporter of trade liberalization [31]. According to the Ministry of Trade and Industry of Singapore, the EAC provides the opportunity for firms in Singapore such as allowing firms to get more inexpensive materials as tariffs in ASEAN calm down, more straightforward exporting process as customs procedures being simplified, gaining access into ASEAN easier as market barriers are removed, and having more opportunities to find skilled labor in ASEAN market.

There are pieces of evidence from the discussion about the impact of the ASEAN Economic Community on the association between internationalization and technical efficiency in Singapore-listed firms. Economic integration, such as creating a single market, can influence corporate technical efficiency by simplifying access to a new market with better resources and investment opportunities [32]. Furthermore, economic integration may increase cross-border trade, making firms take advantage of simplified cross-border access [33]. As a result, the 2015 AEC will encourage and enable more Singapore firms to venture abroad and dominate the ASEAN market [11].

H3a. The relationship between DOI and technical efficiency of Singapore-listed firms in the post-AEC period tends to be better off.

The last discussion in this part is to inspect whether state ownership will influence the association between internationalization and technical efficiency during economic integration. SOEs are granted the privilege to access political and government-related resources. Thus, SOEs may benefit from government assistance by receiving funds, capital, technology, land, and information [7]. 
However, SOEs were strategically situated and economically backed to achieve specific political objectives [34]. Due to those reasons, Singapore SOEs during the 2015 ASEAN Economic Community seem to have lower technical efficiency than private-owned companies since they are politically rather than commercially motivated [35].

$\mathrm{H} 3 \mathrm{~b}$. The degree of state ownership moderates the association between DOI and technical efficiency of Singapore-listed firms during the economic integration.

\section{RESEARCH METHODS}

This study looks at the link between DOI and technological efficiency in Singapore-listed firms before and after the 2015 ASEAN Economic Community. The research samples were obtained from Thomson Reuters and Compustat database. Our final dataset includes 177 firms and 1770 firmyear in 31 industries observations after excluding omitted samples with missing data. Furthermore, the year units are traced from 2011 to 2020 to examine the 2015 ASEAN Economic Community.

There are two stages conducted in our research. In the first stage, we generate technical efficiency using labor, capital, operating expense, and net sales as the independent and dependent variables. In addition, we assess technical efficiency in the production function using Stochastic Frontier Analysis (SFA) in Stata v.15. Robert M. Solow (1957) provided the mathematical foundation for growth accounting. He studied a neoclassical production function in which $\mathrm{Y}_{\mathrm{t}}$ is aggregate output, $\mathrm{K}_{\mathrm{t}}$ is physical capital stock, $\mathrm{L}_{\mathrm{t}}$ is labor force, and $\mathrm{A}_{\mathrm{t}}$ is total factor productivity.

$Y_{t}=A_{t} F\left(K_{t}, L_{t}\right)$

Following a few basic adjustments, the equation may be expressed in terms of growth rates for these variables. As a result, the function may be represented as the Cobb-Douglas production function. The aggregate production growth rate may thus be stated using natural logarithms and differentiating both sides of (1) concerning time $t$ as:

$Y / Y=A / A+\alpha\left(K_{\mathrm{t}} / K\right)+(1-\alpha)(L / L)$

Using accessible statistics on production, physical capital, and labor, we can calculate output, physical capital, and labor growth rates. Physical capital and labor growth rates are weighted by (1). These weights correspond to the proportions of capital and labor rental payments in total revenue. TFP growth may be calculated as the residual from (2). The term "residual" refers to the part of the growth that is not accounted for by capital accumulation or increased labor input. As a result, TFP growth is often referred to as the Solow residual.

$A / A=Y / Y-(\alpha(K / K)+(1-\alpha)(L / L))$

The above estimate paints a fairly basic view of the economy for a single year. On the other hand, growth theory econometrics examines a series of years for a statistically significant pattern in the changes of the variables, allowing the Solow residual value to be determined. As a result, the most straightforward computation approach assumes constant rates of change in all variables (obscured by noise). It regresses the data to get the best approximation of these rates in the available historical data. In doing so, we take the natural log of the Cobb- Douglas function:

$$
\begin{aligned}
& \ln (Y(t))=\alpha \ln (K(t))+(1-\alpha)[\ln (L(t))]+(1-\alpha) \\
& {[\ln (A(t))]+\varepsilon(t)}
\end{aligned}
$$

In Stochastic Frontier Analysis, we assume that errorterm $\varepsilon(t)$ includes technical inefficiency $-u(t)$ and error term white noise $v(t): \mathrm{s}(t)=v(t)-$ $u(t)$

Now technical efficiency $\ln (T E)=-u(t)$

After measuring technical efficiency, we will conduct the second step, in which $\ln (T E)$ will be used asa dependent variable:

$$
\begin{aligned}
& \ln (T E(t))=\beta_{1}+\beta_{2} \mathrm{DOI}(t)+\beta_{3} \operatorname{Size}(t)+ \\
& \beta 4 D R(t)+\beta_{5} \mathrm{MI}(t)+\beta_{6} \mathrm{RE}(t)+\beta_{7} \operatorname{SOEs}(t)+ \\
& \beta_{8} \mathrm{DOI}^{2}(t)+\beta_{9} \mathrm{DOI}(t) * \operatorname{SOEs}(t)+ \\
& \beta_{10} \mathrm{DOI}^{2}(t) * \operatorname{SOEs}(t)+\mu(t)
\end{aligned}
$$

Model 7 includes individual influence, square terms of the independent variable to see curvilinear effects, and control variables.

\section{RESULT AND DISCUSSION}

\subsection{The first step: stochastic frontier analysis}

The first step is to extract the value of technical efficiency of Singapore-listed firms from 2011 to 2020 using statistic software Stata v.15, as shown in Table 1. Most individual variables are statistically significant with a positive effect, except labor. It indicates that labor is not one of the most critical factors determining technical efficiency in 
Singapore-listed firms. The distribution of technological efficiency is depicted in Figure 1.

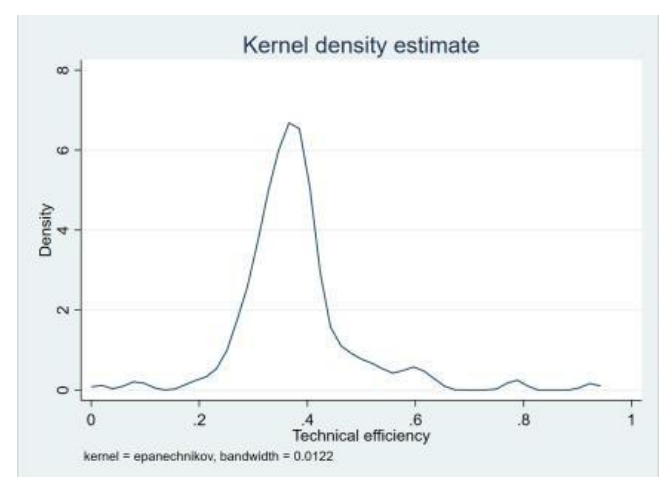

Figure 1. Kdensity of Technical efficiency
The density of Singapore's firm's technical efficiency has an uneven distribution. The majority of a firm's technical efficiency concentration ranges between 0.2 and 0.5 percent, with varying concentrations of the minority of the firm's technical efficiency. This is primarily due to the differences in various industry types in Singapore. Some industry markets may require high technical efficiency levels to thrive, while others may not.

Table 1. Result of Stochastic Frontier Analysis

\begin{tabular}{|c|c|c|c|c|c|c|}
\hline \multicolumn{7}{|c|}{ Dependent variable: Income (Net sales (InY)) of firms } \\
\hline \multirow{2}{*}{$\frac{\operatorname{LnY}}{\operatorname{LnL}}$} & \multirow{2}{*}{$\frac{\text { Coef. }}{.0052087}$} & \multirow{2}{*}{$\frac{\text { Std. Err. }}{.0081911}$} & \multirow{2}{*}{$\frac{z}{0.64}$} & \multirow{2}{*}{$\frac{P>|z|}{0.525}$} & \multicolumn{2}{|c|}{ [95\% Conf. Interval] } \\
\hline & & & & & -.0108455 & .0212629 \\
\hline LnK & .1074696 & .0136901 & 7.85 & 0.000 & .0806375 & .1343017 \\
\hline $\mathrm{LnOE}$ & .9717462 & .0128184 & 75.81 & 0.000 & .9466227 & .9968697 \\
\hline _cons & .0356329 & .221301 & 0.16 & 0.872 & -.398109 & .4693748 \\
\hline$/ \mathrm{mu}$ & 1.074514 & .1557921 & 6.90 & 0.000 & .7691672 & 1.379861 \\
\hline /eta & -.0136345 & .0028837 & -4.73 & 0.000 & -.0192865 & -.0079825 \\
\hline /Insigma2 & -1.523472 & .094715 & -16.08 & 0.000 & -1.70911 & -1.337835 \\
\hline /lgtgamma & .9422224 & .1375626 & 6.85 & 0.000 & .6726046 & 1.21184 \\
\hline sigma2 & .2179537 & .0206435 & & & 1810268 & .2624133 \\
\hline Gamma & .7195484 & .0277599 & & & .6620861 & .7706244 \\
\hline sigma_u2 & .1568282 & .0205953 & & & .1164621 & .1971944 \\
\hline sigma_v2 & .0611255 & .0022509 & & & .0567138 & .0655372 \\
\hline
\end{tabular}

\subsection{The second step: GLS regression result}

The second step examines the degree of internationalization, and technical efficiency of Singapore-listed enterprises are related, with the degree of state ownership mitigating the link from 2011 to 2020, as shown in Table 2 .

Model 1 is the baseline regression model, showing the correlation between control and dependent variables. In this model, all control variables are significantly correlated to the dependent variable; in particular, retained earnings $(\mathrm{p}<0.001)$ positively correlate with technical efficiency. On the other hand, firm size $(p<0.001)$, debt ratio $(\mathrm{p}<0.001)$, and marketing intensity $(\mathrm{p}<0.001)$ are negatively related to technical efficiency.

Model 2 includes the independent variable, degree of internationalization, and the moderator, state-ownership. The results of model 2 show DOI is significantly and positively related to technical efficiency $(p<0.001)$, whereas the squared term of DOI presents a negative relationship with technical efficiency $(p<0.001)$. Furthermore, we discover that state ownership has a negative and significant 
impact on technical efficiency, implying firms with a higher.

In model 3, we include the interaction terms internationalization and state ownership to investigate the moderating influence of internationalization on the relationship between internationalization and Singapore-listed enterprises. Notably, the interaction terms of internationalization and state ownership present a negative and significant relationship with technical efficiency $(p<0.01)$, whereas the squared term of interaction terms is significant and positively related to technical efficiency $(\mathrm{p}<0.01)$.

To verify the first hypothesis, we apply model 2 and determine that the link between internationalization and technological efficiency is inverted U-shaped. At first, DOI is positively associated with technical efficiency $(\mathrm{p}<0.001)$, then after that, it is adversely correlated with technical efficiency $(p<0.001)$. Thus, hypothesis 1 is validated and displayed in figure 2 .

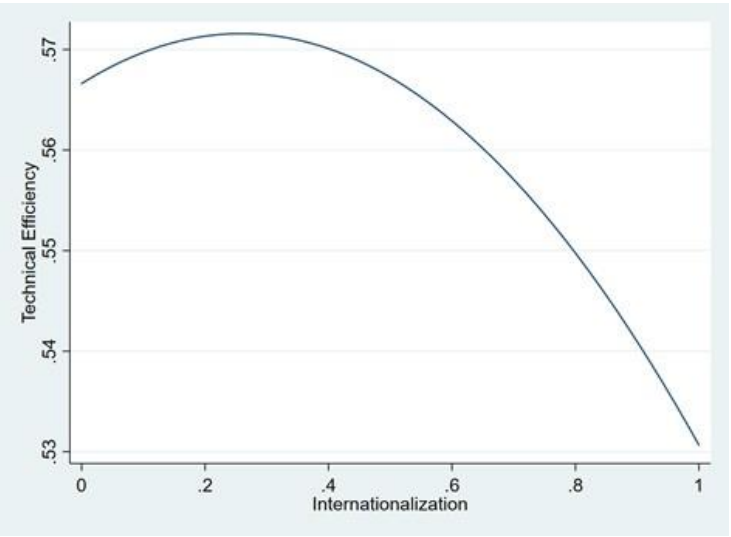

Figure 2. Relationship between DOI and Technical Efficiency

Figure 2 shows that a low degree of internationalization $(0-40 \%)$ increases technical efficiency since firms have access to cheaper or better resources in the international market. Then, as firms reach a high level of internationalization, they will be unable to maintain their technical efficiency

Table 2. Result of GLS regression due to high coordination, distribution, management costs, and information overload. According to our findings, Singapore-listed companies with a medium degree of internationalization (below 40\%) perform better than those with a high degree of internationalization.

Hypothesis 2 proposes that the degree of state ownership moderates the relationship between internationalization and technical efficiency of Singapore-listed firms. In model 3, the interaction term of internationalization and state ownership is negatively and statistically significant $(\mathrm{p}<0.01)$; moreover, the quadratic term of internationalization and state ownership is positively and statistically related to technical efficiency $(p<0.01)$. The moderating effect of state ownership is shown in figure 3 .

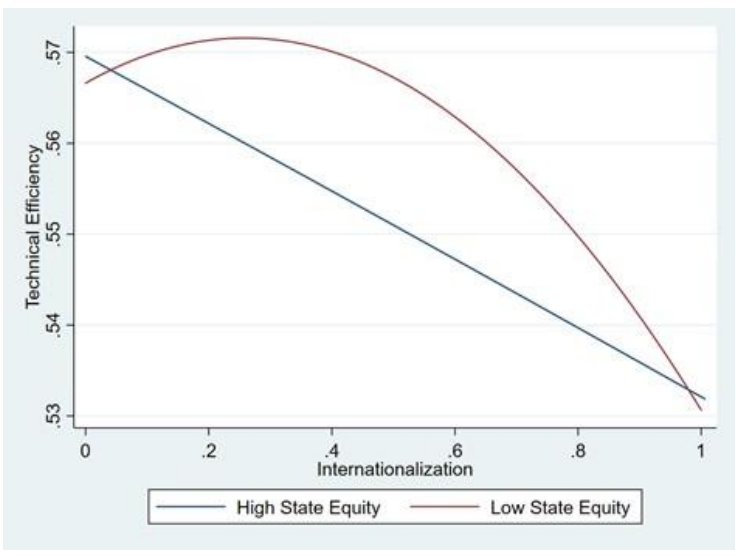

Figure 3. The moderating effect of state ownership

Figure 3 shows that low state equity firms have higher technical efficiency than high state equity firms in a medium degree of internationalization. Notably, high state equity firms outperform low degree state equity when the degree of internationalization is low (below 10\%) and high (surpass 90\%). Consequently, hypothesis 2 is supported owing to the undeniable fact that state ownership determines the internationalizationtechnical efficiency of Singapore-listed companies.

\begin{tabular}{lccc}
\hline Model & $(1)$ & $(2)$ & (3) \\
\hline Firm size & TE & TE & TE \\
Debt ratio & $-0.0147^{\star \star \star}$ & $-0.0136^{\star \star \star}$ & $-0.0136^{\star \star \star}$ \\
Marketing Intensity & $-0.0144^{\star \star \star}$ & $-0.0130^{\star \star \star}$ & $-0.0128^{\star \star \star}$ \\
Retained earnings & $-0.00592^{\star \star \star}$ & $-0.00615^{\star \star \star}$ & $-0.00613^{\star \star \star}$ \\
& $0.0121^{\star \star \star}$ & $0.0125^{\star \star \star}$ & $0.0123^{\star \star \star}$
\end{tabular}




\begin{tabular}{|c|c|c|c|}
\hline Internationalization & & $0.0336^{* * *}$ & $0.0385^{* * *}$ \\
\hline Internationalization² & & $-0.0705^{\star \star \star}$ & $-0.0744^{\star * *}$ \\
\hline State ownership & & $-0.0543^{\star \star \star}$ & 0.0134 \\
\hline $\begin{array}{l}\text { State ownership } \mathrm{x} \\
\text { Internationalization }\end{array}$ & & & $-0.342^{* *}$ \\
\hline $\begin{array}{l}\text { State ownership x } \\
\text { Internationalization² }\end{array}$ & & & $0.335^{\star \star}$ \\
\hline _cons & $0.582^{* \star *}$ & $0.569^{\star \star \star}$ & $0.567^{\star \star \star}$ \\
\hline $\bar{N}$ & 1588 & 1588 & 1588 \\
\hline
\end{tabular}

We further investigate hypothesis 3 and divide the study into two stages based on the effect of the 2015 ASEAN Economic Community. Stage 1 covers the period from 2011 to 2015 , while stage 2 covers 2016 to 2020. Therefore, we use the Chow test to determine whether the coefficients estimated over one data group are equal to those estimated over the other. The Chow test result indicates no support for the null hypothesis, which indicates that the slope and intercept of internationalization significantly differ (see Appendices, Figure 4). In particular, the null hypothesis is that degree of internationalization throughout both periods of preeconomic integration and post-economic integration share the same slope and intercept.

Thus, the slope and intercept of degrees of internationalization in the pre-economic and posteconomic integration periods are depicted in figure 5 .

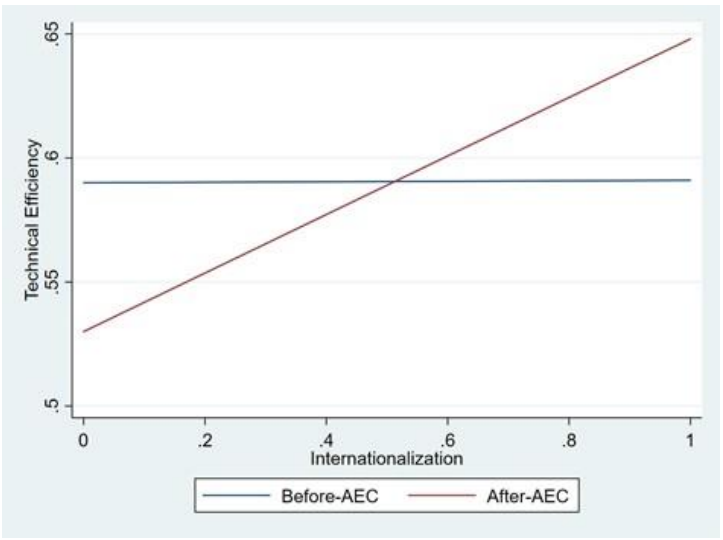

Figure 5. Slope and intercept of internationalization before-AEC and after-AEC

Figure 5 shows that when Singapore firms increase their international activity during the preeconomic integration phase, their technical efficiency increases slightly. On the other hand, the intercept of firms after the ASEAN Economic
Community is significantly increasing higher than those before economic integration, explaining internationalization and technical efficiency are positively correlated after the economic integration. Accordingly, hypothesis $3 \mathrm{a}$ is supported.

Furthermore, hypothesis $3 \mathrm{~b}$ assumes that the degree of state ownership moderates the relationship between internationalization and technical efficiency of Singapore-listed firms during the 2015 ASEAN Economic Community. Accordingly, Figures 6 and 7 demonstrate the moderating effect of state ownership over the pre-integration to postintegration period.

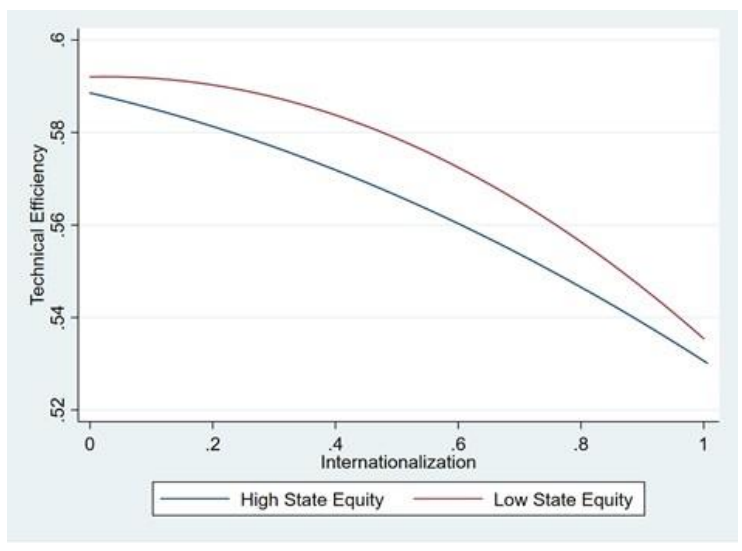

Figure 6. The moderating effect of state ownership on internationalization in the pre-AEC period 


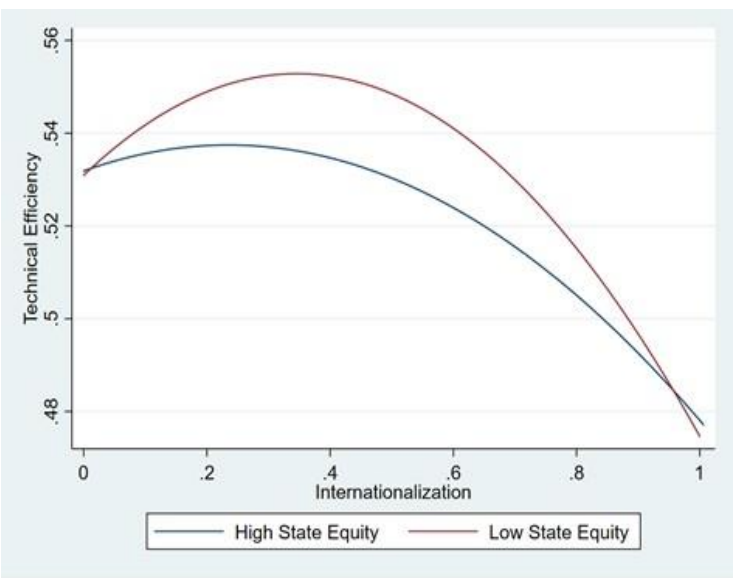

Figure 7. The moderating effect of state ownership on internationalization in the post-AEC period

In summary, firms with a high degree of state equity before the economic integration tend to decrease technical efficiency when they operate internationally. However, they tend to perform better after economic integration initially and operate internationally. Furthermore, low state ownership firms decrease their technical efficiency during the pre-economic integration period. However, the technical efficiency can be increased even more in the post-economic integration period by increasing international involvement at a medium level. However, the moderating effect of state ownership on internationalization is mostly not statistically significant. As a result, the above findings partially support Hypothesis $3 \mathrm{~b}$.

The three-dimensional graph also helps us visualize the interaction between independent, dependent, and moderator variables. Following are the three-dimensional graphs of state ownership and internationalization related to the technical efficiency of Singapore-listed firms.

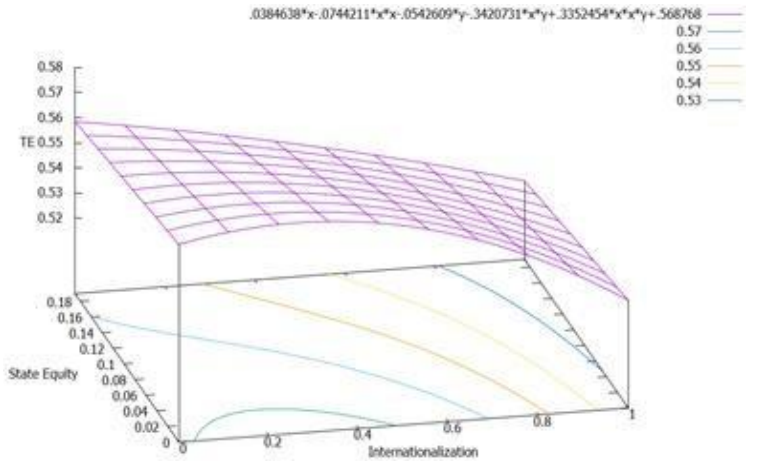

Figure 8. Three-dimensional graph of the joint effect of state ownership
According to figure 8, the configuration of a low degree of internationalization and low degree of state equity achieves the highest technical efficiency. Notably, the technical efficiency decreases gradually as internationalization increases under high degrees of state equity. Meanwhile, firms with a low degree of state equity would initially increase technical efficiency with a degree of internationalization ranging from $0 \%$ to $40 \%$; however, technical efficiency decreases once internationalization exceeds $50 \%$. In addition, we also find that firms with a low degree of state equity concentrate on $75 \%$ to $100 \%$ of internationalization generate the worst technical efficiency. The findings suggest that privately-owned enterprises should focus on low up to a medium degree of internationalization to keep their technical efficiency high. In contrast, state-owned enterprises should either operate domestically or conduct privatization before expanding globally to increase performance and be more technically efficient.

\section{CONCLUSION}

\subsection{Discussion}

The findings of this study support the first hypothesis, implying an inverted U-shaped link between internationalization and technical efficiency of Singapore-listed enterprises. The peculiarities of the Singapore context, including the small domestic market and the upward pressure on costs, encourage Singapore- listed firms to internationalize. Internationalization would increase the technical efficiency of Singapore-listed firms in the early stages as they begin to increase their level of foreign involvement. As foreign involvement increases beyond forty percent, technical efficiency decreases gradually. Moreover, "bigger is not better" [36]. The incremental expenses of further international growth surpass the incremental advantages in this scenario due to high coordination, distribution, and management costs and information overload. Hence, further internationalization is disadvantageous.

Additionally, we discover that the extent to which a state owns technology is a moderator in the link between internationalization and technical efficiency of Singapore-listed firms. Low state equity firms lead to better technical efficiency in a medium degree of internationalization. However, high state equity firms outperform low degree state equity when internationalization is low and high. The results show that a high degree of state-owned enterprises benefit from early stages of internationalization, as they become more 
technically efficient and thrive on the international market. Their government supports them easily in financing, capital, technology, land, and information and makes government policies more conducive for operations development. Consequently, state-owned enterprises can easily reap the benefits of internationalization, resulting in improved technical efficiency.

The following finding clearly shows that the internationalization strategy improves the technical efficiency of Singapore firms during the 2015 ASEAN Economic Community. It indicates that a more accessible flow of capital and skills is necessary for the internationalization of Singaporelisted firms, improving firm technical efficiency. According to Singapore's Ministry of Trade and Industry, from 2016 to 2020, international trade in Singapore increased by around $11 \%$ due to the removal of trade barriers. Therefore, it can be concluded that Singapore firms in post-economic integration exhibited better technical efficiency.

Additionally, we discover that state ownership is a substantial factor influencing the relationship between internationalization and technical efficiency, both before and after the introduction of the ASEAN Economic Community. During the preeconomic integration period, internationalization would decrease the technical efficiency of both a high degree of state ownership and a low degree of state ownership. Furthermore, during the posteconomic integration period, low state equity firms tend to have better technical efficiency in a medium degree of internationalization. In contrast, high degree state equity outperforms low degree state equity when a degree of internationalization is low and high

Mainly, the incline result at the early internationalization of high state equity firms in the post-economic integration may be explained by the Singapore economic transformation plan implemented on 24th March 2016 to address the challenges related to digital technology that Singapore firms face in the international market. The government will spend over USD 4.5 billion over the next five years to grow and venture their businesses into the international market. The program pledges support for firms, exceptionally high state equity firms, exploring foreign markets to increase value creation and innovation by helping businesses develop extensive capabilities, implement technology, expand their size, and internationalize. In consequence, firms are likely to have high technical efficiency during internationalization.

\subsection{Manajerial Implication}

Despite the numerous constraints they face, Singapore firms should internationalize because the benefits of internationalization appear to outweigh the costs. However, Singapore-listed firms should internationalize at an optimum point due to a link between internationalization and an inverted Ushape and technical efficiency. Singapore managers should anticipate a decrease in technical efficiency as a rising level of internationalization incorporates more organizational and environmental complexity, hindering managerial capacity. It may also be necessary for the Singapore managers to analyze firm and market conditions and address the issue of which increase their talents in areas such as branding and marketing, technological development, finance, and other managerial competencies necessary for worldwide expansion to preserve improve their technical efficiency.

Secondly, state ownership is not a barrier to reaping the benefits of internationalization; it may be an advantage. Furthermore, low state equity firms could significantly enhance technical efficiency and achieve the highest technical efficiency at a medium degree of internationalization. On the other hand, high state ownership has a downward shaped relationship, which means that internationalization decreases technical efficiency. To prevent that, Singapore managers of highly state-owned enterprises should analyze and consider carefully when expanding into international markets. In addition, the internationalization of high state equity firms results in inefficiency, so managers should seriously determine the appropriate mix between state equity and internationalization to optimize technical efficiency.

\subsection{Limitation \& Suggestions for Future Research}

In this study, much more is to be done. Firstly, due to the limitation of the Thomson Routers database, we do not have data on foreign employees and the number of foreign countries. Future research should use those mentioned variables to examine the reliability and consistency of our results. In addition, this research included only internal variables of firms. Adding external variables can increase explanatory power.

\section{AUTHORS' CONTRIBUTIONS}

Conceived the ideas of the study: EKA, \& WP; Performed data collection: EKA; Data Analysis and interpretation: EKA, \& WP; Wrote most of the paper: EKA; Provided revision of the manuscript: EKA, \& WP; Provided grammatical revision of the 
manuscript: EKA, \& WP; Provided access to crucial research components: WP.

\section{ACKNOWLEDGMENTS}

We are grateful to the Business Administration Department of National Yunlin University and Science for their support to join a conference on The International Conference on Economics, Management, and Accounting (ICEMAC), organized by the Management and Accounting Study Program of the University of Nusa Putra, held in Indonesia, December 2021. We are also grateful for the financial support from the Office of International Affairs of National Yunlin University of Science and Technology.

\section{REFERENCES}

[1] Ramirez, C., \& Tan, L., Singapore Inc. Versus the Private Sector: Are GovernmentLinked Companies Different? International Monetary Fund, Vol. 51, No. 3, JSTOR, New York, 2004, pp. 510-528.

[2] Choo, S., Developing an entrepreneurial culture in Singapore: Dream or reality, Asian Affairs, Vol. 36, No. 3, Taylor \& Francis, United Kingdom, 2005, pp. 361-373. DOI: https://doi.org/10.1080/0306837050027633 2.

[3] Heracleous, L., Global trends and implications of the Singapore Experience, International Journal of Public Sector Management, Vol. 12, No. 5, MCB University Press, United Kingdom, Bingley, 1996, pp. 432-444.

[4] Lin, C., Ma, Y., \& Su, D., Corporate governance and firm efficiency: Evidence from China's publicly listed firms, Managerial and Decision Economics, Vol. 30, No. 3, Wiley InterScience, Hoboken, 2009, pp. 193-209. DOI: https://doi.org/10.1002/mde.1447.

[5] Gunasekarage, A., Hess, K., \& Hu, A., The influence of the degree of state ownership and the ownership concentration on the performance of listed Chinese companies, Research in International Business and Finance, Vol. 21, No. 3, Elsevier, Amsterdam, 2007, pp. 379-395. DOI: https://doi.org/10.1016/j.ribaf.2007.02.002.

[6] Wei, Z., Xie, F., \& Zhang, S., Ownership structure and firm value in China's privatized firms: 1991- 2001, Journal of
Financial and Quantitative Analysis, Vol. 40, No. 1, University of Washington, Seattle, 2005, pp. 87-108. DOI: https://doi.org/10.1017/s002210900000175 7

[7] Lu, Y., \& Yao, J., Impact of state ownership and control mechanisms on the performance of group affiliated companies in China, Asia Pacific Journal of Management, Vol. 23, No. 4, Springer, Berlin, Heidelberg, 2006, pp. 485-503.

DOI: https://doi.org/10.1007/s10490-006-9017-0

[8] Benito, G. R. G., Rygh, A., \& Lunnan, R., The benefits of internationalization for stateowned enterprises, Global Strategy Journal, Vol. 6, No. 4, Wiley InterScience, Hoboken, 2016, pp. 269-288. DOI: https://doi.org/10.1002/gsj.1138

[9] Yu, M., State ownership and firm performance: Empirical evidence from Chinese listed companies, China Journal of Accounting Research, Vol. 6, No. 2, Elsevier, Amsterdam, 2013, pp. 75- 87. DOI:

https://doi.org/10.1016/j.cjar.2013.03.003

[10] Austria, M. S., Moving towards an ASEAN Economic Community, East Asia Journal, Vol. 29, No. 2, Springer, Berlin, Heidelberg, 2012, pp. 141-156. https://doi.org/10.1007/s12140-011- 9169-5

[11] Chia, S. Y., Globalization and regionalization: Singapore's trade and FDI, Singapore Economic Review, Vol. 60, No.3, World Scientific, Singapore, 2015, pp. 1-23. DOI:

https://doi.org/10.1142/S021759081550034 4.

[12] Piran, S. F., Lacerda, Daniel P., \& Camargo, M., Analysis, and management of productivity and efficiency in production systems for goods and services, New York, Taylor \& Francis Group, 2020, pp. 5-15.

[13] Roghanian, P., Rasli, A., \& Gheysari, H., Productivity through effectiveness and efficiency in the banking industry, Social and Behavioral Sciences, Vol. 40, Elsevier, Amsterdam, 2012, pp. 550-556. DOI: https://doi.org/10.1016/j.sbspro.2012.03.22 9.

[14] Coelli, T. J., Rao, D. S., O’Donnell, C. J., \& Battese, G. E., An introduction to efficiency and productivity analysis, Australia: Springer, 2005, pp. 1-6. 
[15] Fried, Harold O., Lovell, C. A. Knox, \& Schmidt, Shelton S., The measurement of productive efficiency and productivity growth, New York, Oxford University Press, 2008, pp. 7-20.

[16] Hitt, M. A., Tihanyi, L., Miller, T., \& Connelly, B., International diversification: Antecedents, outcomes, and moderators, Vol. 32, No. 6, Journal of Management, SAGE Publishing, California, 2006, pp. 831-867. DOI: https://doi.org/10.1177/0149206306293575

[17] Hsu, C. C., \& Pereira, A., Internationalization and performance: The moderating effects of organizational learning, The International Journal of Management Science, Vol. 36, No.2, Elsevier, Amsterdam, 2008, pp. 188$205 . \quad$ DOI: https://doi.org/10.1016/j.omega.2006.06.00 4

[18] Capar, N., \& Kotabe, M., The relationship between international diversification and performance in service firms, Journal of International Business Studies, Vol. 34, No.4, Palgrave Macmillan, London, 2003, pp. 345-355. DOI: https://doi.org/10.1057/palgrave.jibs.84000 36

[19] Garbe, J. N., \& Richter, N. F., Causal analysis of the internationalization and performance relationship based on neural networks - advocating the transnational structure, Journal of International Management, Vol. 15, No. 4, Elsevier, Amsterdam, 2009, pp. 413-431. DOI: https://doi.org/10.1016/j.intman.2008.10.00 2

[20] Sun, K. A., \& Lee, S., Determinants of the degree of internationalization for US restaurant firms, International Journal of Hospitality Management, Vol. 33, No. 1, Elsevier, Amsterdam, 2013, pp. 465-474. DOI:

https://doi.org/10.1016/j.ijhm.2012.11.006

[21] Assaf, A. G., Josiassen, A., \& Oh, H., Internationalization and hotel performance: The missing pieces, Tourism Economics, Vol. 22, No. 3, SAGE Publishing, California, 2016, pp. 572- 592. DOI: https://doi.org/10.5367/te.2015.0460

[22] Assaf, A. G., Josiassen, A., Ratchford, B. T., \& Barros, C. P., Internationalization and performance of retail firms: A bayesian dynamic model, Journal of Retailing, Elsevier, Amsterdam, Vol. 88, No. 2, 2012, pp. 191-205. DOI: https://doi.org/10.1016/j.jretai.2011.11.005.

[23] Thomas, D. E., International diversification and firm performance in Mexican firms: A curvilinear relationship? Journal of Business Research, Vol. 59, No. 4, Elsevier, Amsterdam, 2006, pp. 501- 507. DOI: https://doi.org/10.1016/j.jbusres.2005.08.00 8.

[24] Tsai, H. T., Moderators on international diversification of advanced emerging market firms, Journal of Business Research, Vol. 67, No. 6, Elsevier, Amsterdam, 2014, pp. 1243-1248. DOI: https://doi.org/10.1016/j.jbusres.2013.04.00 6.

[25] Pangarkar, N., \& Hussain, S., The internationalization of singaporean small and medium-size enterprises: Drivers and performance outcomes, International Studies of Management and Organization, Vol. 43, No. 2, Taylor \& Francis, United Kingdom, 2013, pp. 30-55. DOI: https://doi.org/10.2753/IMO00208825430202

[26] Huat, C. B., State-owned enterprises, state capitalism and social distribution in Singapore, Pacific Review, Vol. 29, No. 4, Taylor \& Francis, United Kingdom, 2015, pp. 499-521. DOI:https://doi.org/10.1080/09512748.201 5.1022587

[27] Huat, T. C., Privatisation in Singapore: The Success of Public Sector Management, International Journal of Public Sector Management, Vol. 3, No. 1, Emerald Insight, United Kingdom, 1990, pp. 47-57. DOI: https://doi.org/10.1108/0951355901014526 4

[28] Cuervo-Cazurra, A., \& Li, C., State ownership and internationalization: The advantage and disadvantage of states, Journal of World Business, Vol. 56, No. 1, Elsevier, Amsterdam, 2021,pp. 1-18. DOI: https://doi.org/10.1016/j.jwb.2020.101112

[29] Mariotti, S., \& Marzano, R., Relational ownership, institutional context, and internationalization of state-owned enterprises: When and how are multinational 
co-owners a plus? Global Strategy Journal, Vol. 10, No. 4, Wiley InterScience, Hoboken, 2020, pp. 779-812. DOI: https://doi.org/10.1002/gsj.1379

[30] Jetin, Bruno \& Mikic, Mia., ASEAN Economic Community a model for Asiawide regional integration? London, Palgrave Macmillan, 2016, pp. 52.

[31] Grzywacz, A., Singapore's approaches toward ASEAN Integration, International Academic, No. 4, ResearchGate, Germany, 2021, pp. 77-101. DOI: https://doi.org/https://orcid.org/0000-00022214-7199.

[32] Biener, C., Eling, M., \& Wirfs, J. H., The determinants of efficiency and productivity in the Swiss insurance industry, European Journal of Operational Research, Vol. 248, No. 2, Elsevier, Amsterdam, 2016, pp. 703714.

DOI: https://doi.org/10.1016/j.ejor.2015.07.055.

[33] Vencappa, D., Fenn, P., \& Diacon, S., Productivity growth in the European Insurance Industry: Evidence from Life and Non-Life Companies, International Journal of the Economics of Business, Vol. 20, No. 2, Taylor \& Francis, United Kingdom, 2013, pp. 281-305. DOI: https://doi.org/10.1080/13571516.2013.782 979.

[34] Harrison, G. W., Rutherford, T. F., \& Tarr, D. G., Trade liberalization, poverty and efficient equity, Journal of Development Economics, Vol. 71, No. 1, Elsevier, Amsterdam, 2003, pp. 97-128. DOI: https://doi.org/10.1016/S03043878(02)00135-9.
[35] Shepotylo, O., \& Vakhitov, V., Impact of Services Liberalization on Productivity of Manufacturing Firms: Evidence from Ukrainian Firm-Level Data, Economics of Transition, Vol. 23, No. 1, 2010, pp. 1-21. DOI: https://doi.org/10.2139/ssrn.1971133.

[36] Brida, J. G., Ramón-Rodriguez, A. B., SuchDevesa, M. J., \& Driha, O., The inverted-U relationship between the degree of internationalization and the performance: The case of Spanish hotel chains, Tourism Management Perspectives, Vol. 17, Elsevier, Amsterdam, 2016, pp. 72-81. DOI:

https://doi.org/10.1016/j.tmp.2015.12.016 